\title{
GEOSAT 高度計による黒潮および黒潮続流域の広域流動観測
}

\author{
坂井伸一*・水鳥雅文 ${ }^{* *} \cdot$ 柴田 彰***
}

\section{1.はじめに}

衛星高度計は, マイクロ波により衛星直下の海面まで の距離を数 $\mathrm{cm}$ の精度で観測することができ，地上局か らの衛星追跡データなどをもとに計算された衛星の軌道 データを組み合わせることにより，準拠楕円体（モデル 化した地球）から海面までの海面高度を算出できる.こ の得られた海面高度 (SSH) は, ジオイド（等重力ポテ ンシャル面) と海面力学高度 (SSDT) の和として表され, 海面力学高度成分のみを取り出すことができれば，海面 の地衡流を計算することができる。

しかし, 現状では, 精度の良いジオイド・データが得 られていないため, 地衡流を計算できる精度の海面力学 高度を求めることはできない. そのため, これまでの衛 星高度計に関する研究では, 同一軌道法 (Shibata ら, 1990）などにより，時間的に不変なジオイドと平均海面 力学高度を除去し, 海面力学高度の時間変動成分を対象 としたものが中心であった。

本研究では, 衛星高度計 GEOSAT のデータを用いて, 黒潮および黒潮続流域を対象に, 黒潮 (続流) の力学特 性を考慮することにより, 海面力学高度の時間変動成分 から平均海面力学高度を求める新たな手法を提案し, 同 海域の海面力学高度の絶対值を求め, 解析結果を船舶や 人工衛星等による既往の観測結果と比較して, 本手法の 適用性について検討した.

\section{2. 高度計データの解析}

\section{(1) 高度計データの概要}

解析に用いた GEOSAT データは, NODC (National Oceanographic Data Center) 提供の T2 GDRs で, 約 17 日周期で同一地点に戻る繰り返し軌道 (ERM ; Exact Repeat Mission) の観測データである. 図一1に示す海域 を対象に, 1986 年 11 月〜 1988 年 2 月 (サイクル 1 〜イ クル 27）のデータについて解析した.

ただし, GEOSATは，日本付近を北東から南西方向に

\footnotetext{
* 正会員 工修 電力中央研究所 我孫子研究所

** 正会員 工博 電力中央研究所 我孫子研究所

*** 理博 気象研究所
}

通過する下降軌道では欠測が多く，ここでは図中実線で 示した上昇軌道のみを対象として解析を行った。軌道は 全部で 42 パスで, 隣り合う軌道の間隔はおよそ $110 \mathrm{~km}$ 程度である. 軌道方向の距離分解能は $7.5 \mathrm{~km}$ である.

T2 GDRs の生デー夕から海面高度を求めるためには, 電離層における自由電子量の光速補正, 対流圏での乾燥 大気および湿潤大気による光速補正, 海洋および固体地 球の潮汐による高度補正などを施す必要がある(Cheney ら，1991).T2 GDRs には, これらの補正值も同時収録 されており, 本研究ではこの補正值を用いて海面高度を 求めた。

得られた海面高度は次式のように表される（今脇ら, 1990).

$$
\begin{aligned}
S(r, t)= & G(r)+\bar{\zeta}(r)+\zeta^{\prime}(r, t) \\
& +\varepsilon_{s}(r)+\varepsilon_{r}(t)+\varepsilon_{m}(t)
\end{aligned}
$$

ただし, $S(r, t)$ は海面高度, $G(r)$ はジオイド高, $\bar{\zeta}(r)$ は平均海面力学高度, $\zeta(r, t)$ は海面力学高度の時間変動 成分, $\varepsilon_{s}(r)$ は系統的な軌道誤差, $\varepsilon_{r}(t)$ はランダムな軌道 誤差, $\varepsilon_{m}(t)$ は任意の測定誤差, $r$ は距離のパラメータ, $t$ は時間のパラメータである.

Ganeko（1983）によれば，図一1に示した海域におけ るジオイド高は, 最大 $50 \mathrm{~m}$ 程度の高低差がある. 一方, 海面力学高度は, 全球で $\mathrm{rms}$ が $50 \mathrm{~cm}$ 程度, 黒潮などの 最も大きいところで $1 \mathrm{~m} \sim 2 \mathrm{~m}$ 程度であるため，海面高 度から海面力学高度の絶対值を求める場合, ジオイド, および (1) 式の誤差成分を数 $\mathrm{cm}$ の精度で取り除く必要 がある。

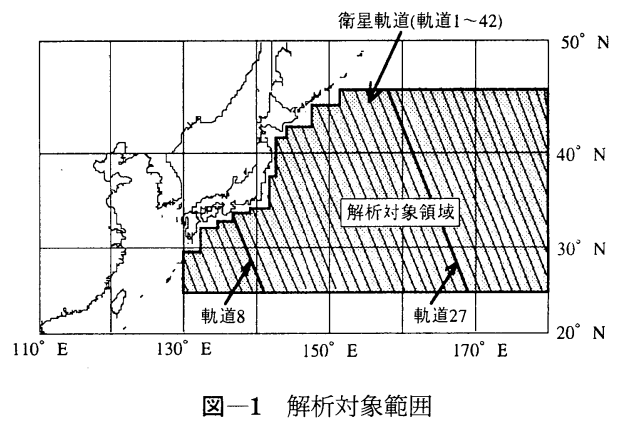


しかし, 現在得られるジオイドデータには, rmsで数 $10 \mathrm{~cm}$ 程度の誤差がある.また, ( 1 ) 式の誤差の中で最も 大きいランダムな軌道誤差には, rms で約 $3 \mathrm{~m}$ 程度の誤 差がある。ただし, Cheneyら（1983）によれば，ランダ 厶な軌道誤差は, 衛星の 1 周期が 1 波長となるような非 常に長い波長であるため, それに比べて短い波長の海洋 現象を対象とする場合には，低次の多項式などにより比 較的容易に分離することができると報告されている。

よって，現状では，ジオイドの不確かさが主要因とな って, 地衡流計算に適用できる数 $\mathrm{cm}$ 精度の海面力学高 度を求めることはできない。

本研究では，次節に示すような，黒潮（続流）の力学 特性を利用した手法を用いることにより，ジオイドデー 夕を用いずに海面力学高度の絶対値を求める.

\section{（2）解析手法}

本研究では, これまでの船舶や人工衛星等による海洋 観測結果から得られている黒潮（続流）の力学特性を考 慮し，以下に挙げる仮定の上で解析を行う。

1）黒潮（続流）は，南側の方が北側よりも約 $1 \mathrm{~m}$ 程 度高い海面力学高度を有する。

2 ) 黒潮(続流)の流軸より南側の海域において海面が 最も高くなるのは黒潮の南端部分，流軸より北側の 海域において海面が最も低くなるのは黒潮の北端部 分である。

3 ）流れの幅（約 $100 \mathrm{~km}$ ）に対して，流路の変動幅の 方が大きい。

上記の仮定を, 図一 1 で示した対象海域に適用し, 海面 力学高度を求める.

ここでは，簡単なモデルを用いて，解析手法の説明を 行う.

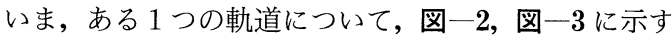
ようなジオイド $(G)$ 分布，および 5 サイクル分の海面力 学高度 $\zeta=\bar{\zeta}+\zeta （$ SSDT 1 SSDT 5) を想定する.ここ で，ジオイドの高低差を約 $10 \mathrm{~m}$ ，黒潮（続流）の横断幅 を約 $100 \mathrm{~km}$ ，黒潮 (続流) の海面力学高度高低差を約 80 $\mathrm{cm}$, 流軸の変動幅を $32^{\circ} \mathrm{N} \sim 35^{\circ} \mathrm{N}$ とした。図 -3 の

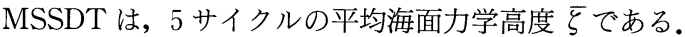

このとき,高度計のデー夕から求められる海面高度 $S$, および平均海面高度 $\bar{S}(\mathrm{MSSH})$ は，図一4のようになる。 実際の観測では前述のように，各種誤差が含まれるが， ここでは簡略化してこれらの誤差を 0 とした。 このとき，平均海面高度 $\bar{S}$ は，以下のようになる。

$$
\bar{S}=G+\bar{\zeta}
$$

次に, 以下の手順で穵を求める。

1）各軌道毎に，各サイクルの海面高度 $S$ から平均海 面高度 $\bar{S}$ を差し引き, 海面力学高度の時間変動成分 $\zeta （ \operatorname{Var} 1 \sim \operatorname{Var} 5)$ を求める（図一5).

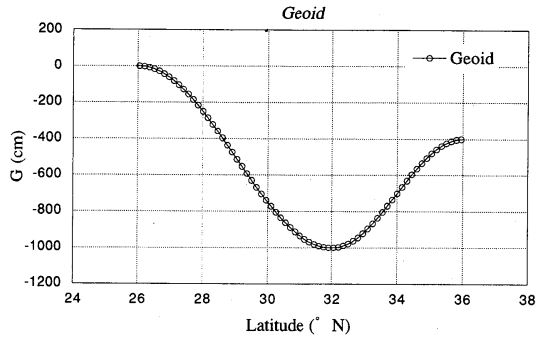

図一2 モデルのジオイド

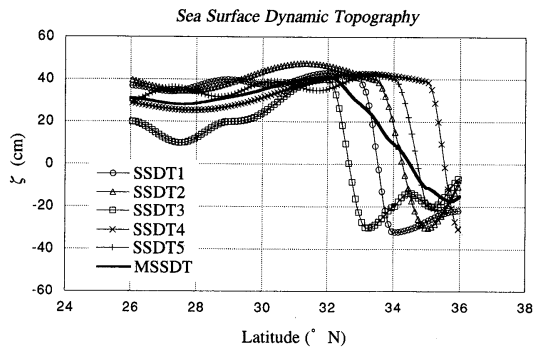

图一3モデルの海面力学高度

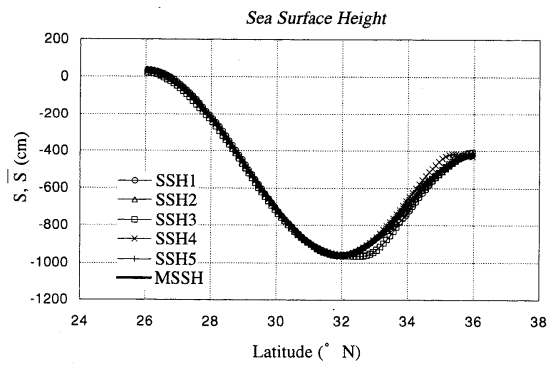

図-4 モデルの海面高度

2 ）各軌道毎に, 全サイクルの との值から, 各緯度に おける最大值 (Max), 最小值 (Min), および両方 の差である振幅 (Amp) を求める。図一6に，Max, Min, Amp，黒潮（続流）が最南端と最北端に位置 する時の海面力学高度, および平均海面力学高度を 示す。

3 ) 图一6において, Ampが最大になる緯度 $\mathrm{N}_{0}$, およ びそのときの值 $\mathrm{Amp}_{0}$ を求める.このとき, 先の 3 ) の仮定より, Amp 0 は黒潮 (続流) の海面力学高度の 高低差を表すことになる．すなわち，黒潮（続流） における海面力学高度の正，および負の部分を $\zeta_{s}$, $\zeta_{n}$ とおくと,

$$
\mathrm{Amp}_{0}=\zeta_{s}+\zeta_{n}
$$

となる。

4 ）先の仮定 2 )により, $\mathrm{N}_{0}$ 以南 $\left(\mathrm{N}<\mathrm{N}_{0}\right)$, および以 北 $\left(\mathrm{N}>\mathrm{N}_{0}\right)$ の海域において，次式が成立する. 


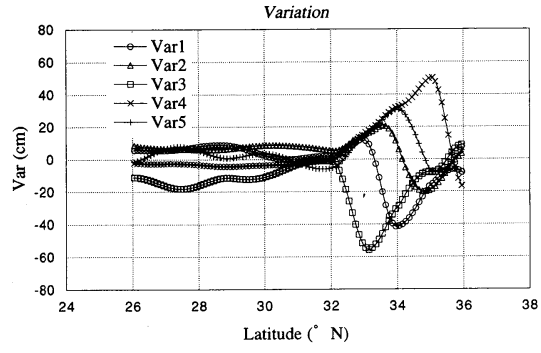

図一5 モデルの海面力学高度の時間変動成分

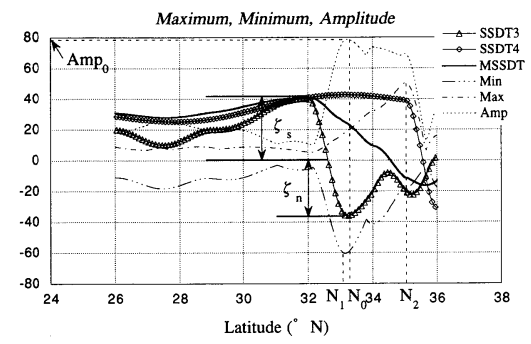

图一6 モデルの Max, Min, Amp

$$
\begin{aligned}
& \operatorname{Max}=\zeta_{s}-\bar{\zeta} \ldots \ldots \ldots \ldots \ldots \\
& \operatorname{Max}-\mathrm{Amp}_{0}=-\zeta_{n}-\bar{\zeta} \\
& \operatorname{Min}=-\zeta_{n}-\bar{\zeta} \ldots \ldots \ldots \ldots \ldots
\end{aligned}
$$

5 ) Min が最小となる緯度を $\mathrm{N}_{1}$ ，Max が最大となる 緯度を $\mathrm{N}_{2}$ として， $\left(\mathrm{N}_{1}+\mathrm{N}_{2}\right) / 2$ の位置における Min の值を $-\zeta_{n}$ と定義して, 上式 $(5),(6)$ 加 $\bar{\zeta}$ を求 める.

\section{3. 解析結果}

\section{（1）軌道上の解析結果}

図一1に示した黒潮流域を通過する軌道 8, ならびに 黒潮続流域を通過する軌道 27 についての解析結果を示 す.

図一7に, 軌道 27 のサイクル 5 における

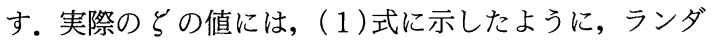
ムな軌道誤差 $\varepsilon_{1}$ と任意の測定誤差 $\varepsilon_{m}$ が含まれる.ここ では, Cheney らにならい, ランダムな軌道誤差 $\varepsilon_{1}$ を, 図一7に実線で示すように， $45^{\circ} \mathrm{S} \sim 45^{\circ} \mathrm{N}$ の範囲に対する 3 次の多項式によって除去した. 任意の測定誤差 $\varepsilon_{m} に$ ついては, 解析結果に与える影響が小さいとして, 本研 究では無視した。

全サイクルについて, 同様にランダムな軌道誤差を除 去し, 前述の解析手順によって, 平均海面力学高度 $\bar{~}$ 求めた。図一 8 に, 軌道 27 に扔ける $\bar{\zeta}$ の分布を示す.

図一8より, $32^{\circ} \mathrm{N} \sim 35^{\circ} \mathrm{N}$ 付近に黒潮続流の流軸が位置 していたことがわかる.また，黒潮続流以南の $27^{\circ} \mathrm{N} \sim 30^{\circ}$ $\mathrm{N}$ の海域に, 反流, ないし冷水塊が存在していたことが

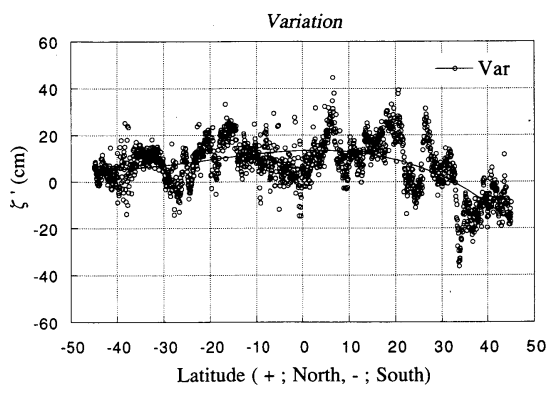

図一7 海面力学高度の時間変動成分（軌道 27）

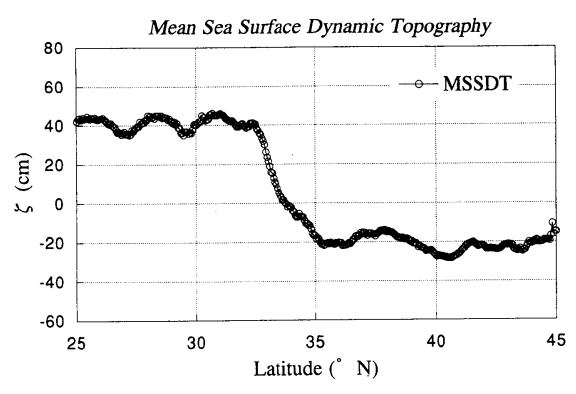

図一8 平均海面力学高度（軌道 27）

推定される.

次に, 各軌道毎に求めた平均海面力学高度 $\bar{\zeta}$, 各サ イクルの時間変動成分 とを足し合わせて, 海面力学高度 の絶対值 $\xi$ を求めた. 図一9, 図一10 に, サイクル 11 に おける軌道 8 , および軌道 27 の海面力学高度を示す.

図一 9 より, 黒潮は $31^{\circ} \mathrm{N}$ 付近に流軸があり, 海面力学 高度の高低差は約 $90 \mathrm{~cm}$ であることがわかる.一方，図 -10 より, 黒潮続流は $31^{\circ} \mathrm{N} \sim 33^{\circ} \mathrm{N}$ に流軸があり, 海面力 学高度の高低差は約 $80 \mathrm{~cm}$ であることがわかる.

地衡流速の絶対値は, 流れの流軸と軌道のなす交差角 がわからない限り, 求めることはできない. 海上保安庁 水路部発行の, サイクル11 とほぼ同時期の海況速報 （図一11）によると, 軌道 8 はほぼ黒潮の流路を直角に通 過していると推定される。そこで, 軌道 8 について, 図 -9 に示した海面力学高度より地衡流速を求めてみる と, 約 $70 \mathrm{~cm} / \mathrm{s}$ となり, 海況速報による観測結果が約 100 $\mathrm{cm} / \mathrm{s}$ であるのに比べて, やや小さくなっている. 観測期 間が正確には一致していないことや，軌道方向の地衡流 分速の実測值がわからないことを考慮すると, 本解析結 果は概ねよい対応を示しているものと思われる。

\section{(2) 平面分布}

軌道毎に得られた解析結果をもとに, $15^{\prime} \times 15^{\prime}$ の格子上 にデー夕を内挿して, 海面力学高度の平面分布を求めた. 前述のように, GEOSAT データは, 隣り合う軌道間隔が $110 \mathrm{~km}$ 程度離れているため, 経度方向に適当なスムージ 


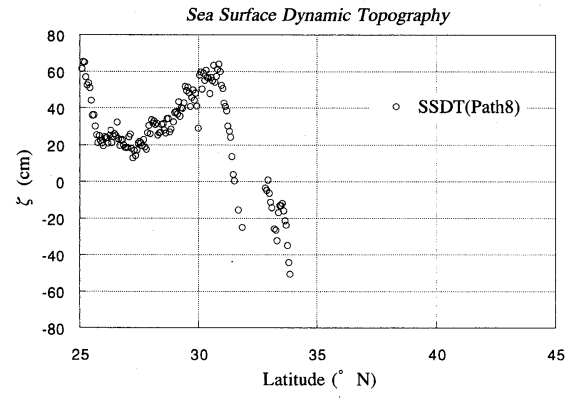

図一9 海面力学高度 (軌道 8 ; 黒潮流域)

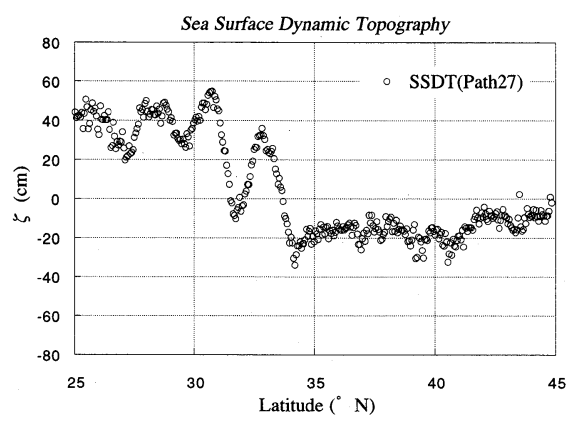

図-10 海面力学高度（軌道 $27 ；$ 黒潮続流域）

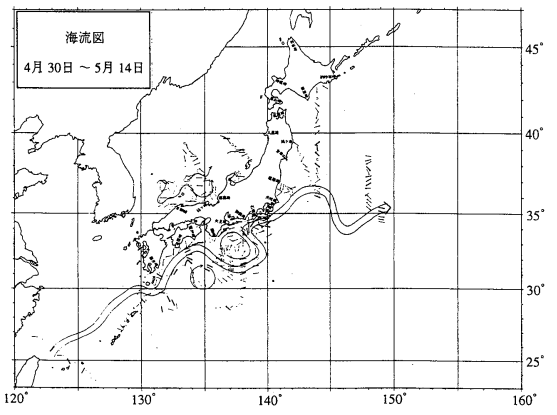

図一11＼cjkstart海況速報による海流図

ング処理を行った。

これまでの船舶等による観測結果より, 黒潮の流路は, 水深 $200 \mathrm{~m}$ 層の水温分布とよく一致することが知られ ている，そこで，解析結果の海面力学高度と海況速報に よる黒潮流域の $200 \mathrm{~m}$ 層の水温分布を比較し，定性的な 黒潮の流路の変動について検討を行った.

図一12〜図一14に，連続する 3 サイクル(サイクル 5 〜サイクル 7 ) の海面力学高度, および $200 \mathrm{~m}$ 層の水温 の平面分布を示す. 海面力学高度の平面分布において, 太線は 0 の等値線を表し，実線は正の值を，点線は負の 值を示している.

両者を比較すると，四国の室戸岬沖から千葉の犬吠埼 付近にかけて，黒潮の流路がよく対応していることがわ

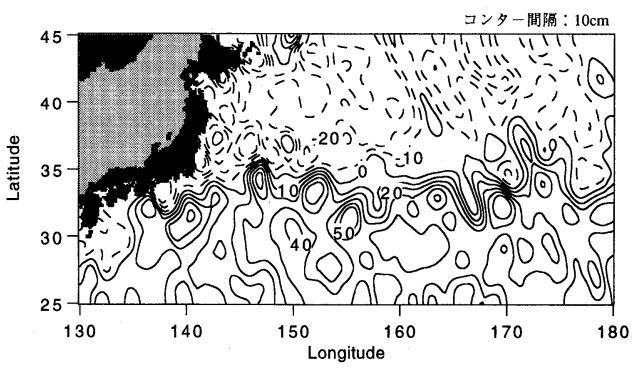

図一12(a) 海面力学高度の水平分布（サイクル 5 )

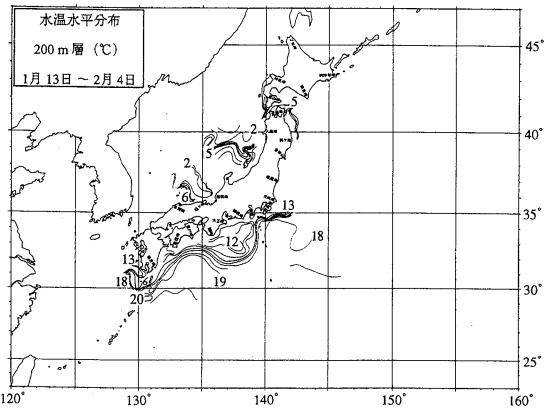

図一12(b) 水温の水平分布（サイクル 5 ）

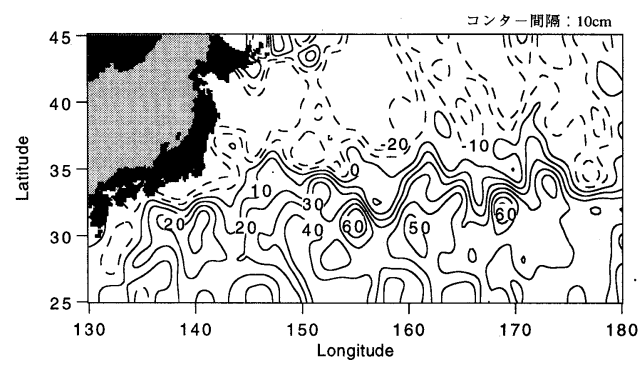

図-13(a) 海面力学高度の水平分布（サイクル 6)

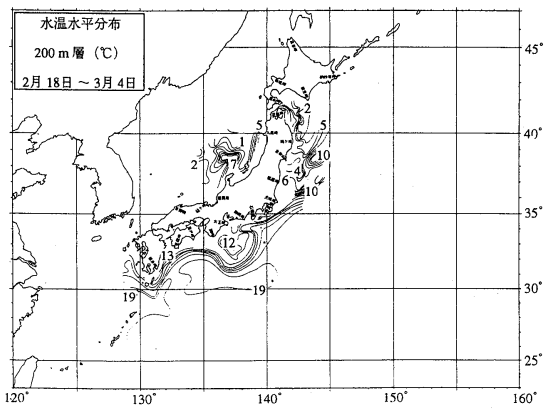

図-13(b) 水温の水平分布（サイクル 6 )

かる。一方，九州の都井岬から室戸岬にかけては，解析 結果に黒潮が表現されておらず，対応が見られない。 ま た, サイクル 6 の海面力学高度には, 紀伊半島の潮岬沖 


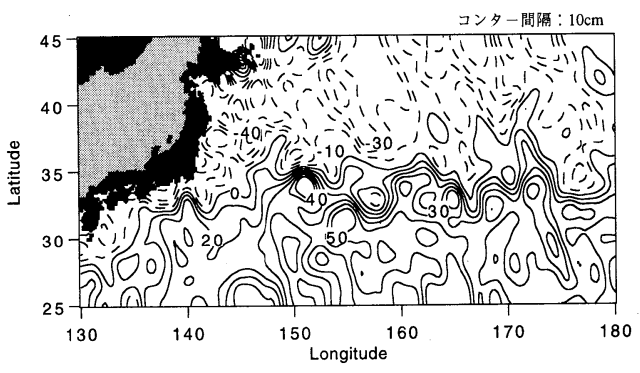

図一14（a）海面力学高度の水平分布（サイクル 7)

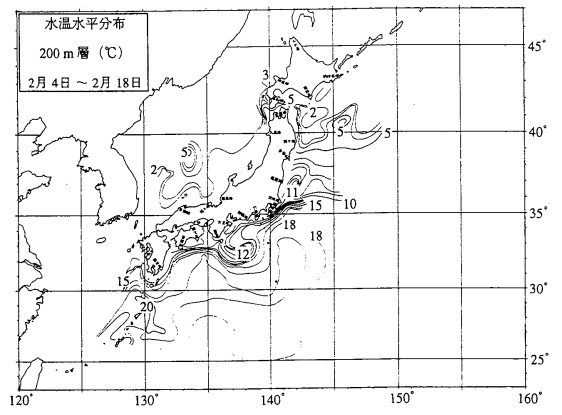

図一14(b) 水温の水平分布（サイクル 7 )

の冷水塊が表現されていない。

次に, 人工衛星 NOAA/AVHRR の海面水温分布画像 を用いて, 黒潮続流域を含むより広範囲について, 解析 結果の検討を行った。ただし, 雲のない良好な画像はサ イクル 6 の期間中の 1 シーンしか得られなかったため, サイクル 6 のみについて検討した.

この結果, 黒潮流域においては, 室戸岬沖から犬吠埼 沖にかけて, 黒潮の流路, 大小の渦, 黒潮反流など, 両 者とも良い対応を示した。また, 水温分布との比較では 対応が見られながった潮岬沖の海域についても良い対応 を示した。一方, 都井岬から室戸岬にかけては, 水温分 布との比較と同様に, 対応が見られなかった。

黒潮続流域では, 複雑に蛇行する黒潮続流の流路や, その周りに存在する中規模渦などが, 両者ともよく一致 した.

図一15には，サイクル 6 における地衡流分布を示す. 前述したように, GEOSAT は下降軌道のデータが使え ないこと, 経度方向の分解能が粗いことなどにより, 定 量的な評価は難しいが, 紀伊半島沖から東の黒潮, およ び黒潮続流とその周りに存在する中規模渦が再現されて いることがわかる. 本手法での仮定が, どの程度の範囲

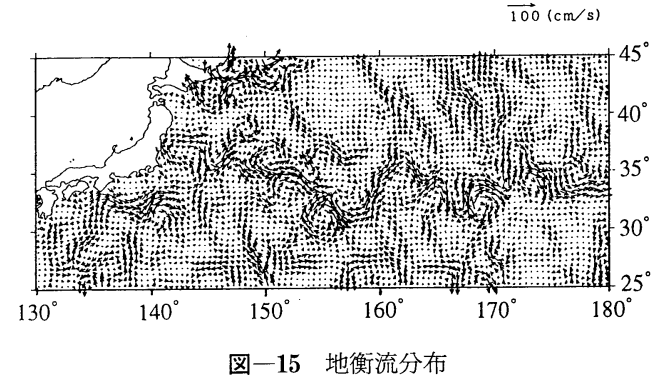

で適用できるかという点については，漂流ブイやより広 範囲の船舶やブイなどの実測データを用いて，検討する 必要があると思われる。

\section{4. ま と め}

GEOSAT 高度計のデータを用いて, 黒潮 (続流) の変 動特性を利用することにより, 海面力学高度の絶対値を 求め, 既往の観測結果などと比較した結果, 概ね良い対 応が得られた. 比較デー夕の精度から定量的な精度の評 価はできないものの, 本手法により, 黒潮および黒潮続 流域の広域流動場を連続して観測できる見通しが得られ た.

一昨年打ち上げられた高度計 TOPEX/POSEIDON は, GEOSATよりも観測精度が良く, 上昇下降軌道とも 良好なデー夕が取得されている.また, わが国周辺の海 域において，同衛星の軌道に沿って国際的な同期観測も 実施されており，TOPEX/POSEIDON の観測データか ら, より精度のよい海面力学高度分布が得られるものと 期待される。

\section{参 考 文 献}

今脇資郎・市川香 (1990)：GEOSAT 海面高度計デー夕から求め た日本近海の海面変動, 月刊海洋, Vol.22, No. 9, pp. 540545 .

Cheney, R. E., J. G. Marsh and B. D. Beckley (1983): Global mesoscale variability from collinear tracks of Seasat altimeter data, J. Geophys. Res., 88 (C 7), pp. 4343-4354.

Cheney, R. E., N. S. Doyle, B. C. Douglas, R. W. Agreen, L. Miller, E. L. Timmerman, and D. C. McAdoo (1991): The Complete Geosat Altimeter GDR Handbook, NOAA Manual NOS NGS 7, 79 p.

Ganeko, Y. (1983): A 10' $\times 10^{\prime}$ detailed gravimetric geoid around Japan, Marine Geodesy, 7, pp. 291-314.

Shibata, A., and Y. Kitamura (1990): Geosat sea level variability in the tropical Pacific in the period from November 1986 to February 1989, Obtained by collinear Method, The Oceanographical Magazine, Vol. 40, pp. 1-26. 